\title{
Frivilliga organisationer, socialt arbete och expertis
}

\section{ANNA MEEUWISSE \& SUNE SUNESSON}

I denna artikel diskuterar vi expertisbildning och professionalisering i frivilliga organisationer på det sociala området.

Det finns två infallsvinklar i texten: dels vill vi se den allt större tonvikten på expertis och professionalitet som en följd av professionaliseringsdiskussionen $i$ socialt arbete, dels undersöker vi hur denna utveckling förhåller sig till organisationernas demokratiska karaktär.

Välfärdsstaternas utveckling har lett fram till en internationell diskussion om socialt arbete och frivilliga organisationer. Några centrala frågor i denna diskussion gäller professionalisering kontra sunt förnuft och amatörism, och expertis kontra lekmannainflytande och demokrati. Frivilliga organisationer förknippas ofta på ett förenklat sätt med amatörism och demokrati - och offentligt socialt arbete med professionell styrning. I själva verket finns det en rad mellanpositioner. Frivilliga organisationer har spelat en viktig roll för det sociala arbetets professionalisering. Idag finner man tendenser till någon form av expertis-

Anna Meeuwisse, fil.dr i socialt arbete, forskar om frivilliga organisationer och vårdsystem för psykiatripatienter vid Socialhögskolan i Lund och Sköndalsinstitutet i Farsta.

Sune Sunesson, är professor i socialt arbete vid Socialhögskolan i Lund. bildning inom många frivilliga organisationer, men också organisationer som motverkar en sådan utveckling. Kooptering framstår här som en viktig process som utlöses av spänningen mellan demokrati och expertutveckling och grundar sig i det politiska systemets behov av att utnyttja organisationernas kontakter och kompetens.

I denna artikel diskuterar vi både frivilligorganisationernas roll för det sociala arbetets professionalisering, och expertisbildning och demokrati i olika typer av organisationer inom den sociala frivilligsektorn.

\section{Det sociala arbetets professionalisering}

Vid det förra sekelskiftet hade fattigvårdsordningarna i vår del av världen råkat $\mathrm{i}$ kris. Utvecklingen av "den sociala frågan", in- 
dustriarbetarbefolkningens levnadsvillkor, hade sedan länge sprängt ramarna för de församlingsbaserade fattigsystem som ursprungligen inrättades under 1500-talet och början av 1600-talet. Den engelska New Poor Law (som infördes 1834), med fattighusinspärrning som straff för fattigdom, hade blivit föremål för folkligt motstånd och offentligt missnöje. Arbetarrörelsen, nykterhetsrörelsen, rösträttsrörelser och kvinnorörelser i olika länder uppmärksammade de fattigas villkor. Den filantropiska rörelsen försökte uppfinna en moderniserad, humanistisk fattigvård, som anknöt till den gamla lokalsamhällesanknutna sockenfattigvården, med dess personkännedom och patriarkaliska ansvarsrelationer, där ortens rika och uppsatta medborgare bestämde över hjälpen till de fattiga på platsen. Dessa försök utmynnade i s.k. "vårdarsystem", där kommunal socialhjälp vävdes samman med frivilliga insatser från överordnade borgare. Dessa system blev som Hans Swärd (1997) har demonstrerat snart politiskt omöjliga. De överlevde inte den politiska demokratiseringen.

I land efter land utformades i stället "socialhjälpsstaten " (för att använda ett uttryck från Seip, 1984) som en offentlig byråkrati under demokratiskt styre. Filantropin fanns kvar, nu som påtryckarorganisationer som utövade s.k. "vetenskaplig filantropi» och påverkade den institutionella utformningen av välfärdssystemet, verkade för barnavård och alkoholistlagar, och påskyndade utbildningen för de nya tjänstemännen i välfärdssystemen (Boalt \& Bergryd, 1974; Lundström, 1997). Några decennier in på 1900talet hade flera länder socialarbetarutbildning på akademisk nivå. I Sverige tillkom den 1921, ungefär samtidigt som den inleddes i England (vid London School of Economics), och några år efter att de första akademiska socialarbetarutbildningarna börjat i USA.

I viktiga avseenden var emellertid fattiglagstraditionen fortfarande stark $i$ de nya systemen. Innehållet i fattigvården och de praktiska arrangemangen i arbetet avgjordes lokalt och stigma sågs fortfarande som ett politiskt nödvändigt uppfostringsmedel. Både fattiglagstraditionen och de institutionella kraven på att de utbildade socialarbetarna skall lösa tillfälligt, oftast "professionsexternt» definierade problem (i Sverige t.ex. ligapojks-problemet vid sekelskiftet; sedlighet, utespring och nöjeslystnad under trettiotalet; raggarungdomens fasoner under femtiotalet, jfr Sunesson 1992) gör att utrymmet för egen utveckling av professionella positioner i detta arbete har varit litet. Därav kommer det amerikanska begreppet nsemi-professionella", ett kontroversiellt uttryck som vållat mycken bitterhet bland socialarbetare och socialarbetarutbildare.

I organisationer som fattigvården förutsätter professionalisering en förändring, att lokalpolitiker och byråkrater abdikerar eller avstår från inflytande och dessutom lämnar utrymmet åt en bestämd yrkesgrupp. Den vanligaste formen för detta är som Magali Larson (1977) uttrycker det "ett socialt kontrakt« mellan professionen och staten. Läkaryrket lyckades inte få till stånd ett sådant avtal förrän efter många hundra års läkarutbildning, och efter en stenhård kamp mot närliggande yrken. Rätten att dominera ett yrkesfält ges inte bort med lätt hand. Att socialt arbete aldrig kommit i närheten av en sådan position behöver kanske inte påpekas. 
Den amerikanske universitetsreformatorn Abraham Flexner (1915) som utformade den första moderna läkarutbildningen, höll 1915 ett föredrag om socialt arbete. Han ställde frågan om socialt arbete verkligen kunde vara eller bli en riktig profession, alltså en sådan som läkaryrket. Svaret var inte så positivt. Endast den som kan hänvisa till en kunskapsbas sådan som läkarnas, kan vara en modern profession. Politiker och organisationsföreträdare skall inte kunna bestämma en professions yrkesinnehåll, menade Flexner.

Samtidigt är det uppenbart att den särställning som den professionelle har är lika lockande för de utbildade socialarbetarna som för andra högutbildade grupper. Detta kommer till uttryck i den indirekta kamp man bedriver för att få sin "rätt» till erkännande och inflytande respekterad. Eftersom den mest inflytelserika professionssociologin (Parsons, 1951; 1954) motiverar professionens "sociala kontrakt" med att yrkena har en utvecklad etik, blir formulerandet av etiska koder ett viktigt argument för rätten att betraktas som professionella yrkesutövare. Detta gäller även för socialarbetare. I denna ambition kommer också den del av frivillighetstraditionen som förknippas med amatörism att bli de professionssträvande socialarbetarnas fiende.

\section{Välfärdsstat och frivilligsektor}

Samtidigt som kraven på utbildning och expertis i människobehandlande yrken synes öka, kritiseras också de utbildade socialarbetarna och de organisationer de arbetar inom. Denna kritik är ibland riktad mot so- cialarbetarnas professionaliseringssträvanden. Hans Zetterberg har t.ex. i några tidningsartiklar i Dagens Nyheter hävdat att socialarbetarna inte bör utveckla egna kunskapsbaser, eftersom detta kan skymma deras uppgift: att vara kommunens tjänstemän, som skall förverkliga förtroendemännens beslut, inget annat. En annan, vagare opposition finns bland dem som menar att akademiskt utbildade tjänstemän tenderar att förstå klienter och klienters förhållanden sämre än andra, som då betecknas som "medmänniskor" eller "amatörer" (Beckman, 1981). Professionalisering och långa utbildningar leder till att socialarbetarna ytterligare fjärmar sig från det som borde ligga i fokus för deras uppmärksamhet, den behövande.

Kritiken mot välfärdsprofessionerna är dock i regel förenad med en mer allmän kritik mot välfärdsstaten, som också lett till en ökad betoning av det frivilliga sociala arbetet (se t.ex. SOU 1993:82; Amnå (red) 1995; Lundström, 1995 a och b ). Inställningen till frivilligt socialt arbete $i$ vårt land har varit delad under lång tid. Antagandet att det alltid skulle råda motsättningsfyllda och konfliktladdade relationer mellan staten och de frivilliga organisationerna är inte historiskt korrekt. Många studier visar det motsatta, nämligen att förhållandet tidvis kännetecknats av samarbete, integration och ömsesidigt beroende och att de frivilliga organisationerna ofta varit en väsentlig drivkraft i etableringen av välfärdsstaten (för en översikt se Gidron, Kramer \& Salomon, 1992, inl.). Sverige är ett av de länder där samhället ständigt, länge i ökande omfattning, har gett stöd till frivilligt socialt arbete i många former. Det har gällt de soci- 
ala insatserna i idrottsrörelsen, handikapprörelsen, klientorganisationer, självhjälpsorganisationer och privata och kooperativa behandlingsinitiativ. Fastän den svenska socialtjänsten, försäkringssystemet och hälsooch sjukvårdssystemet vid en internationell jämförelse kan förefalla så dominerande, finns det sedan länge en lång rad organisationer utanför staten och den offentliga sektorn som på olika sätt arbetar med, och har inflytande på sociala frågor (Jeppsson Grassman och Svedberg, 1995; Lundström \& Wijkström, 1995). De varierar från sådana internationellt vanliga sammanslutningar som Röda Korset eller Riksföreningen mot Cancer till pensionärernas förhandlingsorganisationer (PRO och SPF), patientrörelser som de psoriasissjukas organisation, över anhörigorganisationer som Riksförbundet för utvecklingsstörda barn, ungdomar och vuxna (FUB) och Intresseföreningen för schizofreni (IFS), till "klientorganisationerna".

Det som ibland tolkats som motstånd mot socialt arbete utanför stat och kommun har främst varit motstånd mot välgörenhet och privatisering, snarare än motstånd mot folkrörelser och frivilligorganisationer. Det patriarkaliska fattigsamhället där den hjälpbehövande skall tacka och bocka för välgörenheten symboliserar motsatsen till generell och rättighetspräglad socialpolitik. Det är få som skulle kunna tänka sig möjligheten av en återgång till en sådan politik, och de flesta politiker, även långt in i det borgerliga lägret, använder det orättvisa fattigsamhället som retorisk motbild till det rättvisa samhälle de anser sig kämpa för.

Att frivilligorganisationerna nu lyfts fram i ljuset och tillskrivs en rad positiva värden (som medmänsklighet, värme, engagemang, kreativitet, spontanitet, flexibilitet, autonomi, demokrati) hänger samman med välfärdsstatens kris, och dess ekonomiska, politiska och moraliska förtecken (Lorentzen 1994; Antman (red) 1993; Trädgårdh (red) 1995 ). Det finns en internationell tendens att betrakta frivilligorganisationerna som mindre byråkratiska och mer innovativa än offentliga aktörer. De förväntas kunna producera en social service som både är billigare och mer flexibel, samtidigt som de antas operera på basis av solidaritet. Ännu viktigare är frivilligsektorns ideologiska roll som motföreställning till välfärdsstaten. Detta synsätt har djup förankring i några nu inflytelserika sociologiska teorier.

Håkon Lorentzen (1994) uppmärksammar två moderna, välfärdskritiska strömningar som tar sin utgångspunkt $i$ »det civila samhället«: en amerikansk och en kontinental. Båda räknas till det han kallar »tillhörighetstraditionen" (i motsats till "rättighetstraditionen(I). Tillhörighetstraditionen fokuserar frågor om social tillhörighet och social integration. Det moderna samhället anses befinna sig i en djup kris med tilltagande desintegration och försvagade sociala band. Det hävdas att en offentlig välfärdsapparat oavsett ekonomiska tillgångar står handfallen inför den grundläggande problematiken: professionella kan aldrig utgöra människors sociala nätverk och förmår inte skapa social identitet eller mening i livet. Problematiken låter sig med andra ord inte lösas med bättre ekonomi, fler rättigheter eller fler professionsutövare utan kräver helt nya lösningar och perspektiv. Den ena riktningen inom tillhörighetstraditionen hämtar sin inspiration från den nordamerikanska kommuni- 
taristiska rörelsen som betonar behovet av att stärka människors moraliska förpliktelser (se t.ex. Etzioni, 1993; Waltzer, 1992). Den rättighetsbaserade välfärdspolitiken har enligt detta synsätt försvagat människors förmåga att uppträda socialt och kollektivt, varför det civila samhället måste revitaliseras. I "tillhörighetstraditionens" kontinentala tappning utgör det civila samhället en sfär för experiment med alternativa organisationsformer. I den tyska vänsterdebatten märks Jürgen Habermas' (1987) teser om hur staten koloniserar livsvärlden och Claus Offes (1985) visioner om nya självförvaltande sociala nätverk som är undandragna statens, professionernas och marknadens kontroll. Självstyrande, lokala nätverk förväntas frambringa nya former av solidaritet.

Som en följd av välfärdsstatens kris har de avtal som byggts upp mellan staten och många frivilligorganisationer i de skandinaviska länderna börjat att förändra karaktär. På ett överordnat plan utmärks dagens utveckling dels av att välfärdsstaten börjar dra sig tillbaka inom vissa områden, dels av att allt fler uppgifter förs över till kommunal nivå (Sunesson m.fl., 1998). Samtidigt riktas nya förväntningar på de frivilliga organisationerna. Frivilligt socialt arbete börjar betraktas som en naturlig och integrerad del av den kommunala socialpolitikens åtgärdsarsenal och det har uppstått nya hybridiserade organisationsformer mellan offentligt och privat. Den här integreringsprocessen följs enligt Lars S. Henriksen (1996) av en annan, men intimt förbunden, förändringsprocess i de frivilliga organisationernas omgivning; professionalisering. De frivilliga sociala arbetets ökade sociala status har med- fört ett ökat professionellt intresse för dess "verktyg", "gränser» och "roller». De professionellas intresse av att definiera och avgränsa de frivilliga sociala arbetets legitima arbetsområde och -metoder, bidrar i sin tur till att tänkesätt och praxisformer inom den frivilliga organiseringen professionaliseras. För de frivilliga organisationerna betyder tendensen till hybridisering sannolikt att det blir svårare att upprätthålla autonomi. Men det är inte alltid »de frivilliga» som får anpassa sig efter det offentliga, även offentliga aktörer övertar tänkesätt och praxisformer som traditionellt förbundits med frivilligsektorn.

Det finns tendenser som tyder på en ökad betoning av frivilligsektorns roll som "välfärdsproducent" och försök att uppifrån styra och påverka utbudet i en given riktning (Bergmark, 1994; Lundström \& Wijkström, 1995; Svedberg, 1996a och b; Selle, 1996). I och med att välfärdsstaten drar sig tillbaka förväntas frivilligsektorn överta offentliga omsorgsuppgifter, bli entreprenörer och serviceleverantörer. Stöd som tidigare utgått ovillkorligt och generellt, även för socialpolitisk aktivitet, omvandlas i ökande grad till ersättning för bestämda tjänster. Detta kommer att ställa nya formella krav på de frivilliga organisationerna. I USA går det så långt att de ansvariga i dessa organisationer avkrävs professionell legitimation för att få vara med att utföra sociala tjänster.

\section{Skilda förutsättningar, olika strategier och kooptering}

Det är orimligt att utgå från att alla frivilligorganisationer skulle fungera likadant eller ens ha några gemensamma egenskaper utö- 
ver att inte vara offentliga. När man undersöker frivilligorganisationer finner man inte alltid empiriskt stöd för de stereotypa förväntningar de ofta förbinds med. Deras roll och betydelse varierar beroende på vad de arbetar med, vilken grupp de vänder sig till och vilket samhällssystem de verkar i. I forskningen om frivilliga organisationer blir därför skillnader allt viktigare, olikhet mer än likhet sätts i fokus (Gidron, Kramer \& Salamon, 1992).

Kontrollen inom frivilliga organisationer kan ibland vara mycket hård, diskussionen är inte alltid öppen och demokratin kan sättas ur spel. Ibland betonas expertis och professionell status, ibland framstår detta som ett farligt hot för verksamheten. Sociala rörelser, som är knutna till förändrings- eller uppbyggnadsprocesser, karakteriseras ofta som öppna och flexibla, men som Göran Ahrne (1994) påpekar, tyder många studier på att detta endast gäller i begynnelseskedet när rörelserna är nya. Några av de första klassikerna i empirisk politisk sociologi handlade ju just om hur oligarkier bildas $i$ demokratiska frivilliga organisationer - Michels' järnlag handlar inte om staten, utan om frivilliga organisationer (Michels, 1915).

För att växa eller överleva använder frivilligorganisationer olika strategier i förhållande till omgivningen, t.ex. formanpassning, samverkan, koalitionsbildning, expertisbildning eller protest.

Förmågan att uttrycka sakkunskap på ett område är ofta ett viktigt medel för frivilligorganisationer att nå inflytande. Begreppet kooptering kommer ursprungligen från Robert Michels men har framförallt använts av Philip Selznick (1949) för att beskriva ett förhållande mellan myndigheter och gräs- rotsorganisationer. Kooptering innebär att hotfulla element neutraliseras genom att de ges plats i beslutsprocessen, eller offentligt stöd i olika former. Från statens synpunkt har kooptering den dubbla fördelen att en aura av respektabilitet efter hand överförs från de koopterade delarna till förvaltningen som helhet vilket underlättar förvaltningens auktoritet inom en samhällssektor, samtidigt som det också garanterar myndigheten god tillgång till den koopterade organisationens expertis. Organisationerna går med på detta, eftersom det gör dem starkare och ger dem mer inflytande. Men kooptering förutsätter ofta att organisationerna anpassar sig efter krav och förväntningar utifrån. En brukarorganisation behandlas t.ex. som en grupp av experter på sin egen situation, snarare än som en motvikt eller motmakt. Detta leder också till spänningar mellan basmedlemmar och koopterade ledningar i de frivilliga organisationerna.

Vi skall ge exempel på några frivilliga organisationer som funnit olika lägen mellan kooptering och motkultur. Låt oss dessförinnan försöka skilja mellan två slags frivilliga organisationer.

\section{Två typer av frivilliga organisationer}

Å ena sidan har vi välgörenhetsorganisationer, behandlingsorganisationer och externa stödrörelser. $\AA$ den andra sidan har vi brukarnas egna organisationer. Här finner vi organisationer för förtryckta och drabbade, handikappade, problembärare och vanliga vårdkonsumenter. I det första fallet gäller verksamhetsprincipen »jag för dig, vi för 
dem", i det andra fallet snarare "jag och vi för oss och migu . Kjeld Høgsbro (1992) skiljer på liknande sätt mellan "filantropiskt socialt arbete« som innebär försök att lösa andra människors problem, "igångsatt självhjälp» som engagerar dem som själva har problemen men som är styrd och igångsatt av andra, och "självorganiserad självhjälp" där de som själva har problemen planerar och utvecklar aktiviteterna. (Se även Lundström, 1997, sid 9-10.)

Sådana här indelningar skall naturligtvis inte styra tänkandet för mycket, eftersom det finns hybrider: En organisation för anhöriga till personer med ett visst problem är en mellanform, liksom en nykterhetsrörelse. Organisationer är inte bara hybrider i själva verksamheten, de kan också vara indelade i divisioner som har olika karaktär i detta avseende och ha olika karaktär på olika nivåer. En organisation som ursprungligen var en påtryckningsorganisation bland föräldrar och anhöriga till handikappade barn kan ha utvecklat nya vitala delar: en självhjälpsorganisation för nyblivna föräldrar, en annan organisation som utvecklar utbildning för handikappade $i$ en form som kombinerar självhjälp och bildningsfolkrörelse, och slutligen också en barn- och ungdomsorganisation för de funktionshindrade barnen själva.

\section{"Jag för dig-organisationer"}

Man kan skilja mellan tre typer av organisationer inom denna kategori.

A. Den första typen är den enkla amatöristiska hjälp-eller välgörenhetsorganisationen, ofta lokala en- eller fåfrågeorganisationer. Dagens Nyheter den 5.12. 1997 porträtterar ett sådant initiativ: "Systrar ger utslag- na en riktig jul. Nyktert och värdigt firande. Egna erfarenheter av problem gav idén«. Två unga systrar, tillika servitriser, hyr den enas arbetsplats på julafton, och tillsammans med några vänner ordnar de en valternativ jul« för ensamma och utslagna i en restaurang på Kungsholmen i Stockholm.

Detta är ett exempel som sluter sig till en tradition av klassisk, "vertikalt" organiserad hjälpverksamhet (Qvarsell, 1993). Under 1800-talet växte det i många städer fram filantropiska sällskap som främst organiserade medelklasskvinnor.

Att sprida kristna och "värdiga» livsideal och levnadssätt ingick som en mer eller mindre dold förutsättning för verksamheten. Hjälpen byggdes upp kring personliga kontakter och hade huvudsakligen en individualistisk inriktning. Man skulle enligt principen "hjälp till självhjälp» hjälpa nödlidande på ett sådant sätt (ekonomiskt och/ eller moraliskt) att de så snart som möjligt kunde klara sig själva utan att ligga det allmänna till last. Denna välgörenhet rymde dock insatser av mycket olika slag. Filantroper kunde - och kan - vara mer eller mindre solidariska, avantgardistiska och paternalistiska. Även om uppfostran i borgerliga ideal och skötsamhet har varit ett dominerande tema, förekommer det både anarkistiska och antimoralistiska initiativ.

I de enkla välgörenhetsorganisationerna förväntar vi oss inte ett särskilt omfattande inflytande från "brukarna", även om deras medverkan kan vara nödvändig - som i julfirandet vi nämnde. Vi hittar sällan professionella roller för de aktiva deltagarna.

B. Den andra typen utgörs av differentierade organisationer, som ofta har administra- 
tiv och professionell personal utöver frivilligt aktiva. Här finner man också organisationer som har tagit akademiska initiativ och grundat skolor och högskolor. Centralförbundet för socialt arbete, CSA, grundade Socialinstitutet i Stockholm; Röda Korset en känd sjuksköterskeskola. CSA var remissinstans och gjorde egna utredningar i början av seklet, och det finns vittnesmål om många filantropiska sammanslutningar som påbörjat utvärderingar och forskningsprogram. Den första systematiska utvärderingen inom hela det område vi idag kallar "socialt arbete" gjordes av Sophie van Zanden Theis på uppdrag av en stor välgörenhetsorganisation i New York och utmynnade i utvärderingsrapporten »How Foster Children Turn Out« (1924). Mary Richmond utvecklade case-worktraditionen i och på uppdrag av en organisation inom denna "vetenskapliga filantropi». Det var också på uppdrag av det nationella förbundet för filantropi (Charities and Corrections) som Abraham Flexner (1915) fällde sitt profetiska omdöme om möjligheterna för socialt arbete att bli en kunskapsorienterad profession.

Många nutida organisationer kombinerar filantropi och expertis - vi kan nämna Röda Korset, Rädda Barnen, BRIS - alla är delar av denna tradition. Många av dessa organisationer är i dagens läge beroende av offentligt stöd, både opinionsmässigt och ekonomiskt. Vissa av dem är känsliga för »budgetpåtryckningaru, som kan påverkas av offentlig kritik. Ibland har de nått en så stor genomslagskraft att de framstår som, eller gärna framställer sig som den organisation som är den "rätta» företrädaren eller servicegivaren, som Hassela-rörelsen tidvis gjorde un- der sjuttio-och åttiotalet när det gällde unga narkomaner, eller Noaks Ark - Röda Korset, när det gäller hiv och aids (Magnusson, 1997).

I denna typ av organisationer är frågan om demokrati och expertis mer komplicerad än i de enkla välgörenhetsinitiativen. Vissa är centraliserade, som »Läkare utan gränser" medan andra har bred demokratisk karaktär, som Afrika-grupperna. Det är därför omöjligt att uttala sig generellt om brukarnas möjligheter att påverka dessa organisationer. Somliga har bildats med ett uttalat syfte att vara demokratiska, eller rent av att skapa demokratiskt inflytande på sina områden som företrädare för brukarna eller andra som är engagerade i frågan.

Några av dessa organisationer anställer administrativ personal och utbildade socialarbetare ungefär som en offentligt ägd verksamhet hade gjort. Det gäller idag för t.ex. Rädda barnen, och för många av Röda Korsets aktiviteter (Lundström, 1997). En organisation som Riksförbundet för sexuell upplysning (RFSU) är ett exempel på en modell för expertmedverkan som blir allt vanligare. Där engageras experter (läkare, barnmorskor och kuratorer) som frivilliga i organisationens arbete (Magnusson, 1996).

C. Den tredje organisationstypen kallar vi "settlementorganisationer" eller "settlementrörelser« efter en tradition i socialt förändringsarbete. I den moderna formen är dessa organisationer ofta initierade av professionella eller intellektuella och/eller av personer med personlig erfarenhet av ett problem. »Jag för dig» blir i dessa organisationer också »du är nödvändig", dvs. brukarna involveras aktivt i verksamheten. Settlementorganisatio- 
ner baserar sig ofta på stiftelser som arbetar relativt självständigt i förhållande till andra organisationer. Organisationerna har en relativt avgränsbar ledning och styrelse, som arbetar för att skapa utrymme för verksamheter såsom allaktivitetshus, fritidsgårdar, härbärgen, skyddscentra, arbetsstugor, matbespisningar etc., för personer i viss ålder, i vissa lokalområden eller med vissa behov. Dessa verksamheter kan definieras lokalt (ungdomar på Möllevången) etniskt (för unga arabiska flickor eller för kurdiska pojkar) eller i sociala problemtermer: hemlösa, drogmissbrukare, misshandlade, f.d. psykiatripatienter.

Traditionen har en viktig utgångspunkt $\mathrm{i}$ Jane Addams, och hennes Hull House i det förra sekelskiftets Chicago (Davis, 1967; Levin, 1997). De svenska hemgårdarna, t.ex. Birkagården i Stockholm, liksom settlementen på Nörrebro och Vesterbro i Köpenhamn är tidiga utlöpare av den internationella settlementtraditionen (Olson, 1982). Kretsen kring Hull House ville varken ägna sig åt den tidens professionaliserade välgörenhet eller åt moralism, utan istället som grannar och medmänniskor verka för sociala reformer genom närkontakt, utbildning, kulturell verksamhet och utbyte av erfarenheter. Till skillnad från andra differentierade frivilligorganisationer för socialt arbete är settlementorganisationen inte en behandlingsorganisation, utan en verksamhet som strävar efter integration och stöd $i$ vardagslivet, dvs. just så som Jane Addams hus i Chicago fungerade. Verksamheten i Hull House dokumenterades och blev föremål för forskning i sociologi och socialt arbete (Breckinridge, 1925). I settlementorganisationerna kan man alltså ibland konstatera en dragning mot professionalisering och expertisbildning, och också ett rent forskningsintresse. Tendensen är emellertid högst motsägelsefull, som framgår av vårt nästa exempel.

San Patrignano är ett uppmärksammat italienskt arbetskooperativ som grundats av en förmögen lekman men som idag bärs upp av mer än $1000 \mathrm{f}$. d. narkotikamissbrukare. En speciell form av rehabilitering har växt fram: ett samhälle i samhället där f.d. missbrukare lever, arbetar och utbildar sig utan professionell vård- eller rehabiliteringspersonal och med ett begränsat stöd från det offentliga (Guidicini \& Pieretto, 1995). Trots att två decennier gått, har San Patrignano ännu inte baserat sitt existensberättigande på expertisanspråk, och modellen bygger inte på rationalism utan fullföljer snarare ett slags lekmannaideal. Den sociala ordningen struktureras av arbete och gemenskap. Den anknyter också till religiösa traditioner där social kontroll, askes, likhet inför Gud och tron på alla människors inneboende möjlighet till förändring betonas.

Eftersom denna typ av organisationer bygger på att de man vänder sig till också skall vara delaktiga i organisationens arbete, kommer vissa framgångsrika settlementrörelser också att bli hybrider - som liknar viför-oss organisationer. De kan också vara sammanympade med påtryckningsorganisationer eller bildningsorganisationer.

\section{"Vi för oss-organisationer"}

Medan de tidigare nämnda organisationerna är föreningar för brukare, kommer vi nu in på föreningar av brukare.

Dessa är "horisontella» organisationer för att skydda gemensamma intressen och stödja dem inom den egna gruppen som drabbas 
av problem. Inom denna tradition kan man nämna det medeltida skråväsendet och det försäkringsväsende som började växa fram inom vissa yrkesgrupper redan på 1700-talet och som så småningom blev en viktig uppgift för fackföreningsrörelsen. Denna självhjälpstradition har en kollektiv inriktning och bygger på principer om solidaritet inom gruppen, och ibland med andra i liknande situationer. Goda exempel är Anonyma Alkoholister (AA), Länkarna, eller klientorganisationer som Alkoholproblematikernas Riksorganisation (ALRO), Riksförbundet för hjälp åt läkemedelsmissbrukare (RFHL) och Riksförbundet för Social och Mental Hälsa (RSMH).

En del av dessa rörelser utvecklar sig till renodlade kamporganisationer, som Riksförbundet för Kriminalvårdens Humanisering (KRUM). Andra är mera inriktade på självhjälpsarbete och gemenskap. Radikala handikapporganisationer tar ibland avstånd från den annars så heliga integrationstanken, för att istället betona rätten till frizoner för dem som är annorlunda (Mallander, Meeuwisse \& Sunesson, 1998). I några av de föreningar som betonar rätten till gemenskap och tillhörighet utvecklas subkulturer där uttrycken för natt vara annorlundau får ett särskilt värde.

Under de senaste åren har sådana krav också fått stöd och sympati i samhällsvetenskapen, där sociala problem undersökts som socialt konstruerade problem (Sunesson, 1992; Spector \& Kitsuse, 1977). De negativa definitionerna, "problemen", har i regel myntats av politiker och administratörer, inte av alkoholister, narkomaner och prostituerade själva. Hela frågan om definitionen av vad eller vem som är problemet blir naturligtvis en helt annan, om de själva gör definitionerna. I viss grad delar dock dessa människor den negativa bild av dem själva som så många i samhället gärna vill förmedla, och organiseringen innebär därför alltid en ansträngning att ändra både självbilden och bilden av gruppen inför offentligheten. Independent-living rörelsens kamp för att de funktionshindrade också formellt och explicit skall ha rätten att definiera sina behov och servicekrav, är ett exempel på radikal omkonstruktion av en underlägesposition (Morris, 1993; Gough, 1994).

Demokrati och brukarinflytande är självklara utgångspunkter i »vi för oss-organisationeru. Det kan dock - här som annars vara svårt att undgå byråkratisering när organisationerna växer sig starka. Erfarenheten av »vi-för-oss-organisationer» i Sverige visar att de kan bli formellt fria att definiera sina problem och också handla för att lösa dem på olika sätt. Men deras ställning kan också leda till kooptering och underordning i systemet.

De flesta vi- för- oss organisationerna har i ökande grad fått behov att förklara sina ståndpunkter för politiker och allmänhet. Ibland har detta lett till att man utvecklat egen expertis, som pensionärsorganisationernas experter på socialförsäkringssystem, eller till satsningar på forskningsstiftelser och kunskapsspridning. Expertis blir emellertid ett värde även i de organisationer som inte alls vill släppa in utomstående och professionella i verksamheten.

\section{Tre exempel}

Vi skall ge några konkreta exempel på hur några organisationer av de typer vi nu dis- 
kuterat utvecklas i dagens samhälle, vilka påfrestningar de möter, och vilka val de ställs inför. Vi börjar med »settlement-organisationen" klubbhusrörelsen (Meeuwisse, 1997), för att sedan gå över till klientrörelserna Riksförbundet för social och mental hälsa (RSMH) och Riksförbundet för hjälp till läkemedelsmissbrukare (RFHL) (Sunesson, 1989). Vi avslutar med föregångaren bland de moderna självhjälpsrörelselserna, Anonyma Alkoholister (AA) (Helmersson Bergmark, 1995).

\section{Klubbhusrörelsen}

Klubbhusrörelsen, eller Fountain House-rörelsen som den också kallas efter ursprungsstiftelsen i New York, riktar sig till människor med psykiska funktionshinder. Klubbhuset som modell för rehabilitering utvecklades av John Beard som var föreståndare på Fountain House under åren 1955-1982. På 1970-talet fick Fountain House statliga bidrag för att bedriva utbildning i klubbhusmodellen, och många nya klubbhus bildades. På 1980-talet utvecklas verksamheten till en internationell rörelse. I dag finns det omkring 350 klubbhus runt om i världen, bl.a. nio svenska.

Klubbhusmodellen bygger på antagandet att självförtroende och social kapacitet byggs upp genom vänskap, arbete och självstyre. Klubbhusen är huvudsakligen organiserade kring gemensamma, konkreta arbetsuppgifter på dagtid och lokalerna används för sociala aktiviteter på kvällar och helger. Medlemskapet är frivilligt och utan tidsbegränsning. Personalen - ofta men inte alltid utbildade socialarbetare - är anställd för att ge stöd och att garantera kontinuitet. Alla beslut i huset skall fattas i enlighet med de- mokratiska principer och alla skall ha samma tillgång till alla fora, uppgifter och utrymmen i huset.

Verksamheten drivs huvudsakligen med hjälp av statliga och kommunala bidrag, men klubbhusen eftersträvar oberoende i förhållande till den offentliga vården. Många klubbhus är liksom Fountain House och de svenska klubbhusen organiserade som privata stiftelser, men långt ifrån alla. För att tillgodose medlemmarnas och klubbhusens behov skall styrelsen vara sammansatt av personer som besitter kompetens inom skilda fält; det privata näringslivet, bostadssektorn, universitetsvärlden, den sociala sektorn, handikappförbund etc. Målsättningen om oberoende och integritet har framförallt $i$ en del amerikanska klubbhus kommit på skam, då man av ekonomiska skäl ibland tvingats anpassa verksamheten till de formkrav som ställs från omgivningen (t.ex. krav på journalföring och rehabiliteringsplaner). Rörelsen och det arbete som bedrivs inom enskilda klubbhus samordnas bl.a. genom nationella och internationella klubbhuskonferenser där såväl medlemmar och personal som styrelseledamöter deltar.

Det produceras en strid ström interna dokument om klubbhusrörelsen, och många av skrifterna används som underlag vid konferenser och internutbildningar. En del författare blir tongivande och framstår som ett slags "rörelseintellektuellaw. Artiklarna behandlar ofta en viss aspekt av klubbhusmodellen, t.ex. betydelsen av jämlika relationer, frivillighet, oberoende eller "riktigt« arbete, och är starkt ideologiskt färgade.

Som ett led i rörelsens utveckling har den antagit normer, som uttrycker klubbhusmodellens filosofi och praxis i konkreta termer. 
Samtidigt som normerna garanterar medlemmarnas rättigheter och inflytande utgör de gränser för vad som är förhandlingsbart. Det finns idag också särskilda utbildningsprogram och kontrollorgan som skall garantera att verksamheten bedrivs i enlighet med normerna. Dessa fungerar också på internationell nivå och fyller funktionen att säkra resurser till »rätt» verksamheter när konkurrensen på rehabiliteringsområdet hårdnar. Detta innebär också en säregen form av kvalitetssäkring och expertisbildning. Kriteriet för inflytande är engagemang och ideologisk trohet, vilket innebär att gränser mellan olika nationer, klubbhus och personkategorier successivt upphävs.

Att klubbhusen ofta rekryterar inflytelserika människor är ett exempel på kooptering, liksom att man inom de internationella organen knyter till sig externa experter. Husen försöker värna sin autonomi genom en bred rekryteringsbas och bestämmelser om att styrelseledamöter endast får representera "sig själva" och måste se till verksamhetens bästa. Många av de externt rekryterade tycks med tiden införliva klubbhusideologin och bli en del av kulturen. Formellt sett är medlemmarnas och personalens ställning i klubbhusens styrelser svag, men mycket av styrelsearbetet delegeras till särskilda arbetsutskott där de har stort inflytande. I de internationella klubbhusorganen dominerar medlems- och personalrepresentanter. De externt rekryterade experterna ges enbart en rådgivande och informerande funktion.

Genom att upprätta egna normer, utbildningsprogram och kontrollorgan, och därmed också lägga grunden för ett slags pseudoprofessionalism, försöker man skydda sin modell från ovälkomna institutionella krav från omgivningen. Det blir här närmast fråga om ett slags självstyrd institutionalisering för att motverka målförskjutning och för att garantera den inriktning som utformats inom rörelsen. Samtidigt finns det hela tiden en risk för att den höga ambitionen under yttre eller inre tryck leder till förlamning eller byråkratisering.

Under det senaste decenniet har klubbhusrörelsen vunnit möjligheter att påverka vård- och utbildningsutbudet och att fungera som remissinstans när det gäller samhällets skyldigheter för psykiskt funktionshindrade. Klubbhusföreträdare försöker nu också aktivt övertyga utbildningsföreträdare om modellens relevans för socialt arbete.

\section{Två R-förbund}

Riksförbundet för hjälp till läkemedelsmissbrukare, RFHL, bildades 1965, just när "narkotikaproblemet« började bli en erkänd samhällsfara. Det började som en för 1960talet typisk opinionsorganisation, där intellektuella, journalister, radikala socialarbetare och läkare träffades, men sedan dess har RFHL kunnat organisera många f.d. narkotikaanvändare och gäster vid behandlingshem. Uppsvinget för fångarnas organisation och för deras motståndskamp under åren efter 1968 gav draghjälp för att organisera f.d. droganvändare och människor som sökte hjälp och vård för sina narkotikaproblem.

RFHL är idag en mycket professionellt ledd organisation, som framförallt ägnar sig åt riksomfattande och lokala kampanjer, studieverksamhet och politisk påtryckning, och att leda ett antal behandlingshem. Pengarna kommer framförallt från det offentliga, för behandling, studier och t.ex. folkhälso- 
upplysningsarbete. Inemot två tredjedelar av medlemmarna, som är organiserade i c:a 15 lokalorganisationer, är f.d. drogbrukare. De andra är socialarbetare, politiskt intresserade aktivister eller anhöriga till människor som använt - eller använder narkotika eller lugnande medel.

Drog- och narkotikafrågan är full av kontroverser (Peele, 1985; Laursen, 1996). Under den period RFHL funnits till har organisationen nästan hela tiden hållit fast vid några grundläggande idéer. Det är krav på tolerant och human behandling och rätt till vård för droganvändare, och mot utstötning, hårdare lagstiftning och tvångsvård. Samtidigt har RFHL varnat för heroinets och kokainets entréer i Sverige, och bekämpat användningen och förskrivningen av lugnande medel.

RFHL är motståndare till den apokalyptiska synen på narkotikautvecklingen, och gendriver den med statistik och empiriska argument, och är också emot de krigsmetaforer som genomsyrar språkbruket i den dominerande "diskursen" på området, regeringens "offensiva narkotikapolitik", och ifrågasätter om den verkligen är effektiv. RFHL är motståndare till den människosyn, som ligger bakom bilden av narkomanen som en drogstyrd zombie och hävdar i stället att människor kan förändras om de får förutsättningar till det. RFHLs ståndpunkter ligger ofta nära dem som många forskare på drogområdet intar, t.ex. när det gäller tvångslagarna och tvångsvården (Ågren, 1990; Goldberg, 1993).

Organisationernas ambitioner framgår av tidningen Oberoende, som också rapporterar om alla de socialpolitiska initiativ som RFHL tar. På en del områden har de uppnått en viss, erkänd expertis, speciellt efter det att benzodiazepinproblemen - som RFHL tog upp för 25 år sedan - nu blivit internationellt omtalade. Samtidigt är RFHL både direkt och indirekt under ett visst tryck, eftersom organisationen då och då kommer att misstänkliggöras för att vara en fackförening för knarkare eller en propagandacentral för narkotikaintressen. För att få en stabilare position har RFHL fått utveckla nära förbindelser med fackföreningsrörelsen och arbetarrörelsen, med vissa delar av den offentliga sektorn och med en lång rad socialpolitiska och frivilliga sociala organisationer. I TV:s AIDS-gala för snart 10 år sedan deltog RFHL i ledningen tillsammans med bl.a. Röda Korset och under ledning av prinsessan Christina.

RSMH, Riksförbundet för social och mental hälsa, bildades 1967 kring två små grupper av aktiva mentalsjukhuspatienter, men med aktivt stöd från samma sociala skikt som var med om att bilda RFHL. RSMH är en sammanslutning vars medlemmar nästan helt och hållet är patienter och f.d. patienter inom psykiatrin. Det finns 100 lokalavdelningar i Sverige, från början vid och kring de stora mentalsjukhusen (Engman, 1992). RSMH har varit framgångsrikt när det gäller att nå ut till sina potentiella medlemmar, men är uppbyggt på en ständigt skiftande grupp av bräckliga individer. Förbundet försöker bli företrädare för en motkultur, som baserar sig på öppenhet, solidaritet, kamratkontakt och intensiv kritik mot psykiatrin och anti-psykosmedicinerna. Lokalavdelningarna driver öppna dagverksamheter, och är oftast beroende av medel från kommunerna för att klara bl.a. lokalhyra. Att skapa en mötesplats för med- 
lemmarna, som för det mesta är ensamma och isolerade människor, är det viktigaste ändamålet för organisationens lokalföreningar.

På det centrala planet har RSMH en upplysnings- och kampanjverksamhet som inriktar sig på psykiatrins former och brister, och har deltagit - ibland som gisslan - i en rad utredningar, bl.a. den stora psykiatriutredningen.

Avinstitutionaliseringen och det sätt den genomförs har varit föremål för en stor kampanj ("Tillbaka till vad?"), som sedan följts av kampanjer kring genomförandet av psykiatrireformen. En annan av de viktigaste kampanjerna har varit den som förts mot överförskrivningen och det oreflekterade bruket av neuroleptika. Dessa ämnen är några av de viktigaste i tidningen Revansch!

RSMH är en organisation som är välsedd i sin omgivning, och bland alla politiska partier. Bakom detta ligger naturligtvis främst respekt för de f.d. patienternas kamp för erkännande och rättigheter, men också deltagande och sympati. Representanter från RSMH blir hörda av statliga och kommunala myndigheter, har utbildat sig till personliga ombud för tvångsbehandlade, och samarbetar med många socialpolitiska organisationer och grupper inom handikapprörelsen.

\section{Anonyma Alkoholister}

Anonyma Alkoholister (AA) - den första "moderna» självhjälpsgruppen - grundades av två alkoholister i USA 1935, och har med åren utvecklats till en brukarrörelse som är spridd i hela världen. Den grundläggande idén är att alkoholister endast kan räddas genom andra alkoholister och att personlig förändring bara är möjlig genom omvändel- se och andlig övertygelse. Organisationen utmärks av en stark ideologi som motverkar impulser utifrån. Trots de "sekteristiska» dragen har AA lyckats inplantera ett visst tolkningsmönster i det allmänna medvetandet. Att vara "nykter alkoholist» är idag ett vedertaget begrepp. Som social rörelse är AA unik så tillvida att den har överlevt utan större förändringar under mycket lång tid och visat sig effektiv trots ett minimum av administration och organisation.

AA:s verksamhet byggs upp kring regelbundna möten bland gelikar. Det enda som krävs för att bli medlem är att man uttrycker en önskan om att sluta dricka - kampen mot alkoholen förenar medlemmarna. Alkoholism ses som en obotlig sjukdom och det enda som hjälper är att avstå från alkohol för gott. Det kan man få hjälp med av andra alkoholister, en högre makt och "de tolv stegen« till ett nyktert liv. De tolv stegen utgör en kombination av en helig skrift, en livshållning och en metod för att uppnå nykterhet. AA-möten kan man besöka så länge och så ofta man känner behov av det, och på så sätt erbjuds man ett långsiktigt eller t.o.m. livslångt socialt stöd.

AA:s struktur är utöver de tolv stegen uppbyggd kring "tolv traditioner" och "tolv principer« som fungerar som stadgar för all AA-verksamhet. De tolv traditionerna innebär bl.a. att ingen kan uteslutas ur gemenskapen, anonymitetsskydd, att varje grupp skall vara självstyrande, självständig och självförsörjande, att AA skall förbli ickeprofessionellt och ha minsta möjliga organisation.

Att vara expert inom AA, att ha rätten att tala bland och för de anonyma alkoholisterna förutsätter både en egen erfarenhet 
av missbruk, och av kampen mot den egna alkoholismen. Vissa AA-medlemmar tycks uppnå en stor förmåga att förstå de former andras missbruk och beroende tar sig, och får stort förtroende i organisationen. Denna expertis har som sådan ingenting att göra med professionell status.

De tolv traditionerna har starkt bidragit till att $\mathrm{AA}$, i motsats till många andra sociala rörelser, inte fallit offer för oligarkins järnhårda lag, som ofta har interna maktstrider, stagnation och splittring som följd. Anonymitetsprincipen utgör ett hinder för ledarkult och uppbindning kring enskilda personer. Elitbildning och ledarskiktning förhindras också genom förbudet mot egendomsförvärv, principen om rotation på alla förtroendeposter och principen om absolut demokrati. AA-grupper måste dessutom vara fullständigt oberoende av omgivningen. De får inte ta emot ekonomiska bidrag eller själva tjäna pengar.

Men AA är inte opåverkad av omgivningen. Tvärtom är den relativt försvarslös gentemot yttre skeenden som $i$ viss mån påverkar dess utbredningsmöjligheter. AA-rörelsens etablering och utveckling i Sverige illustrerar omgivningsfaktorernas betydelse. Den första svenska AA-gruppen etablerades i början på 1950-talet, men tillväxttakten var under flera decennier låg eftersom AA kom att stå i skuggan av Länkarna. AA kunde inte göra något åt detta. Svårigheterna för AA att etablera sig i Sverige kan bl.a. hänföras till folkrörelserna, sekulariseringen och de socialdemokratiska idealen. Det var först genom den framgångsrika lanseringen av den s.k. Minnesotamodellen i mitten av 1980-talet, som också AA på allvar började nå spridning i landet.
Minnesotamodellen har vuxit fram vid sidan av det renodlade, kontinuerliga självhjälpsarbete som bedrivs inom AA. Den är uppbyggd som ett tidsbegränsat rehabiliteringsprogram med anställd personal bestående av både professionella vårdutövare (läkare, psykologer, sjuksköterskor, socialarbetare) och nyktra alkoholister med specialutbildning (s.k. "alkoholterapeuteri). Det pedagogiskt inriktade behandlingsprogrammet kombineras med AA-ideologi och man förespråkar deltagande i AA efter den ca 5 veckor långa behandlingstiden. Skicklig lansering av en till synes effektiv behandling har bidragit till att Minnesotamodellen konkurrerat ut många andra behandlingsalternativ (Rosenqvist \& Stenius, 1989; Fridell, 1996). I Sverige vann modellen till en början framförallt stöd inom näringslivet, men lyckades så småningom även vinna gehör bland läkare och socialarbetare inom offentlig vård.

AA är på många sätt en saga om wanarkismens triumf", men Nils Christie (1997) ser samtidigt tecken på en begynnande byråkratisering och professionalisering. Trots betoningen av de enskilda AA-grupperna autonomi, har man tillåtit inrättandet av s.k. servicekontor, kommittéer och servicekonferenser, som förvisso skall tjäna grupperna men som samtidigt innebär risk för maktkoncentration och interna stratifikationssystem. De AA-grupper som avviker från traditionerna kan t.ex. strykas från den officiella lista som servicekontoren regelbundet distribuerar. Framväxten av nya behandlingsinstitutioner som erbjuder snabbkurser i de 12 Stegen innebär ett hot mot grundidén om icke-professionalism. När nyktra alkoholister anställs för att handleda andra 
som har alkoholproblem uppstår nya professioner, och den relation som tidigare byggde på ömsesidig hjälp blir i allt högre grad en relation mellan klient och expert. Risken är att lekmännen förlorar tron på sin egen betydelse och kunskap, då utbildad och avlönad personal kan förmodas veta så mycket mer. Inom rättsväsendet kräver man ibland att personer med missbruksproblem skall delta i AA-möten, som en del av bestraffningen eller som ett led i övervakningen av de villkorligt frigivna. Därmed kullkastas också principen om frivillighet och gruppernas karaktär förändras.

\section{Tre slags rörelser - demokrati och expertis}

R-förbunden verkar i det kontroversiella. Frågor om psykiatri och schizofreni är lika kontroversiella som narkotikafrågan (Castel, 1988), men RSMH:s positioner är förmodligen lättare att upprätthålla än RFHL:s. Allmänhetens solidaritet med dem som är med $i$ RSMH är större än med missbrukarna, och respekten för viljan till självorganisering och sympatin för de lokala öppna dagverksamheterna ger RSMH legitimitet. Å andra sidan är RSMH:s positioner när det gäller psykiatri och medicin öppet fientliga mot vad som lärs ut inom det mesta av psykiatrin, både då det gäller schizofrenins ursprung och etiologi, och när det gäller behandlingen av den, och också mot de gällande tvångslagarna.

Narkotikafrågan tvingar RFHL, en organisation som har tusentals före detta narkomaner bland sina medlemmar, till en uppdelad position, där de försvarar människor och mänskliga rättigheter, men inte narkotikan eller drogkulturerna. På det sättet blir den en "företrädare", för många förtryckta människor, men tar hjälp av experter och forskare för att driva sin sak. Resultatet har blivit att RFHL varit mycket framgångsrikt $i$ att hålla en - om än försiktigt - oppositionell röst vid liv i narkotikadebatten. RSMH, däremot, har bibehållit sin karaktär av genuin social rörelse. Det är en organisation som öppnar ett socialt rum för sina medlemmar, och försöker att ge dem rätten att tala utan att disciplinera dem, utan att underförstått begära att de skall acceptera vissa politiska åsikter eller vissa politiska metoder som riktiga. Samtidigt innebär det att RSMH:s inflytande utåt kan bli begränsat, och därmed också både den potential och den risk som det medför att vara företrädare för människor som själva inte kan föra sin talan.

Medan klubbhusen delvis av strategiska skäl väljer att definiera sig som ett neutralt komplement till annan psykiatrisk vård och rehabilitering, har RSMH etablerat sig som en vårdpolitisk motkraft. De skilda rollerna har emellertid med tiden blivit alltmer diffusa. RSMH har, i likhet med såväl klubbhusen som stora delar av den svenska klientrörelsen utvecklat ett gott samarbete med stat och kommun (Jeppson Grassman \& Svedberg, 1993). Samtidigt som organisationen kritiserar den offentliga politiken, ingår den själv i samma politik, både eftersom den är beroende av offentlig finansiering och genom att den utövar visst inflytande över reformer och verksamheter inom det psykiatriska fältet. Initiativ som Forskningsstiftelsen Humlan, vilken skall främja sådan forskning som RSMH finner angelägen, kan ses som försök att uppnå större autonomi via expertisbildning. 
Den rörelseexpertis som bildas i klubbhusorganisationen är också en syntes mellan medlemmarnas, personalens och de utifrån kommande experternas erfarenheter. De kontroverser som diskuteras är oftast interna, som att vissa klubbhus låter personalen kränka normerna, alltså medlemmarnas rättighetsförteckning, eller förvandlas till värmestugor eller vårdcentraler.

AA driver sin egen linje, kritiserar ibland de som påstår motsatsen, men är knappast särskilt engagerade i vare sig alkoholpolitiska frågor eller allmän socialpolitik, och företräder inte medlemmarna som intresserörelse.

\section{Frivilliga organisationer sinsemellan: konkurrens och samarbete}

En frivillig organisations sociala omgivning utgörs till stor del av andra frivilliga organisationer. Förhållandet mellan frivilligorganisationer kan ofta beskrivas i termer av konkurrens eller samarbete, inte sällan bådadera. Samarbete mellan organisationer kan innebära att en organisation påverkar eller till och med skapar en annan organisation som kan ha helt andra uppgifter än den första. Vi skall ge exempel på hur några av »vi för oss-organisationerna" samarbetar och konkurrerar med "jag för dig-organisationer" av settlementtyp.

RSMH har bidragit till etableringen av flera svenska klubbhus och är ofta representerade i styrelserna. När det första svenska klubbhuset bildades 1979 i Stockholm, var det med RSMHs länsavdelning som huvudman och med landstinget och kommunen som huvudfinansiärer. Samarbetet med en patientorganisation kunde skänka det nybildade klubbhuset legitimitet och medlemmar. Tommy Engman, (1992, sid 78) antyder dock i sina intervjuer att det redan tidigt kunde uppstå rivalitet mellan RSMH-föreningar och klubbhus. De motsättningar som ännu ibland flammar upp mellan R-förbundet och klubbhusen beror på att organisationerna har olika målsättningar och hamnar i lokala konkurrensförhållanden. RSMH definierar sig som en »äkta» självhjälpsorganisation, en "motkultur", och vissa RSMHaktivister anser att klubbhusen bygger på en välgörenhetstradition, där verksamheterna styrs av personalen och människor med högt uppsatta positioner i samhället, vilket borgar för moralism och paternalism (Jespersson, 1994). Kritiken mot RSMH kan i sin tur handla om att föreningarna är passiva, sönderslitna av interna konflikter och anarki. Genom sin betoning på brukarinflytande och ett »icke-psykiatriskt " perspektiv gör klubbhusen intrång på RSMHs domän. Man skall ha i åtanke att RSMH och klubbhusen i realiteten konkurrerar om såväl kommunala bidrag som medlemmar.

RFHL har varit en drivande kraft i etableringen av den ideella föreningen Basta Arbetskooperativ, en svensk motsvarighet till settlementorganisationen San Patrignano (Hansson \& Wijkström 1997, se även detta nummer). Det var RFHLs dåvarande förbundssekretare Alec Carlberg som i Sverige presenterade San Patrignano som ett rehabiliteringsalternativ. Till skillnad från den italienska förlagan kom Basta att etableras genom ett samarbete mellan en frivilligorganisation, ett antal kommuner och den svenska staten. RFHL ansvarade för projektering och utbildningsinsatser vilka bekostades av 
Socialstyrelsen och samarbetskommunerna (Carlberg, 1991). Utgångspunkten har dock hela tiden varit att Basta skall styras av sina egna medlemmar (och då bli en "vi för ossorganisation") och på sikt även uppnå ekonomiskt oberoende. Kopplingarna mellan RFHL och Basta är starka, man samverkar t.ex. i ett EU-understött dataprojekt. Ändå upprätthålls tydlig åtskillnad mellan R-förbundet och arbetskooperativet. Basta inriktar sig på att utveckla själva arbetskooperativet och avstår från att ta ställning i drogpolitiken.

Ett annat exempel på arbetsdelning mellan R-förbund, stiftelser och staten kan hämtas från hiv-politikens område (Magnusson, 1996, se även detta nummer). Här finns en rad organisationer med delvis olika roller och målgrupper, vilka staten utnyttjar för olika ändamål. Medan Riksförbundet för sexuell upplysning (RFSU) och Riksförbundet för sexuellt likaberättigande (RFSL) närmast kan beskrivas som folkrörelser med socialpolitiska ambitioner har stiftelsen Noaks ark mer avgränsade uppgifter. Noaks ark ser sig som ett komplement till offentliga myndigheter och har påtagit sig rollen som ett slags socialtjänst för dem som drabbats av hiv och deras anhöriga. Stiftelsen har satsat på att bygga upp expertis på området och lutar sig i huvudsak på medicinska rön. RFSL förhåller sig mer kritisk gentemot vissa renodlade medicinska perspektiv då dessa inte sällan kommer i konflikt med organisationens rättighetspolitik. Ingen av dessa organisationer kan upprätthålla sin nuvarande verksamhet utan statliga hivanslag, vilket dels innebär att de konkurrerar med varandra och dels att de i varierande utsträckning blir offer för kooptering.

\section{Staten och de frivilliga organisationerna: expertis och kooptering}

Frivilliga organisationer på det sociala området har under hela 1900-talet kommit att bli delar av den svenska politiken på sina specialområden. På den punkten skiljer vi oss inte från andra demokratiska länder.

Organisationerna kommer in i den statliga politiken på olika sätt. Det vi kallar kooptering innebär att organisationerna - eller deras företrädare - får vara med att ta ansvar för beslut eller att genomföra delar av en politik. Kooptering sker ofta genom att organisationerna har och visar en stor expertis på ett visst område, och ser en möjlighet att påverka politiken genom att deras egna experter får påverka utformningen av t.ex. ett vårdsystem. I andra fall kan koopteringen ske genom att organisationer erbjuds medlemskap i styrelser och andra beslutsorgan, eller genom att myndigheterna direkt åtar sig att finansiera verksamhet som är särskilt angelägen för organisationen. Organisationernas rörelsefrihet kanske kommer att inskränkas i viss mån, eftersom myndigheter och politiker förväntar sig att de skall vara lojala med ett gemensamt beslut åtminstone i viss tid efter beslutet. Samtidigt skaffar sig organisationerna på detta sätt ett slags skydd och hägn, eftersom de blir officiella samarbetspartners med stat och kommun. Expertisbildning och professionalisering får - och har alltid haft en nyckelroll i denna process (Lundquist, 1997; Magnusson, 1997).

Samtidigt är det så att organisationerna är utomordentligt olika i dessa avseenden. Organisationer som pensionärsförbunden 
har hittills knappast behövt ta till professionalisering och förvetenskapligande för att driva igenom sina argument, däremot är de beroende av fungerande lokala samarbetsformer för sina medlemmars väl. RSMH kan fortsätta att på det lokala planet kräva respekt för sina medlemmars rätt till friutrymmen från arbetslinjer och prestationskrav, samtidigt som de genom central expertis försöker påverka psykiatripolitiken. RFSL, de homosexuellas organisation, bygger upp expertis på alla nivåer, en expertis som både används i kampen för rättigheter och i den omfattande självhjälps- och rådgivningsverksamheten.

Svårigheterna för organisationerna att bibehålla sin identitet och sina ursprungliga syften är emellertid tydliga. När AA:s kompetens får ett marknadsvärde, eller när RSMH och RFHL öppnar behandlingshem, kommer organisationerna därmed att få en annan inriktning än de hade från början. I de senare fallen är detta förenligt med en demokratisk organisationsutveckling. I AA, som i sina grundsatser förbjuder institutionalisering, innebär det en avsöndring som måste ligga utanför själva organisationen, men samtidigt ändå ställer den inför ett indirekt krav på resultat för de nya medlemmar som lotsats dit av vårdapparaten.

När välfärdsstaten drar sig tillbaka förändras också relationerna mellan staten och organisationerna (Sunesson m.fl., 1998). Nya anslagsformer och uttryckliga krav på motprestationer påverkar organisationerna att $i$ än högre grad bli serviceleverantörer och att sälja sin expertis, i stället för att enbart använda sina kunskaper för att uttrycka krav och peka på behov. Lokal kännedom om brukargrupper kommer att kunna bli en bytesvara på samma sätt. En självhjälpsorganisation kan t.ex. avkrävas insatser som att informera en grupp pensionärer eller funktionshindrade om nya kommunala betsämmelser. Detta är ett specialfall av det vi ovan kallat hybridisering, dvs. att organisationer som ursprungligen är "vi-för-oss organisationer» antingen blir mer lika välgörenhetsorganisationer eller settlementorganisationer, eller blir underordnade delar i den offentliga socialtjänsten.

Den "fria korporatism" som Gunnar Heckscher i sin Staten och organisationerna (1951) visar på som det mest karakteristiska draget i svenskt samhällsliv byggde, menade han, på två grundförutsättningar. $\AA$ ena sidan måste organisationerna tillerkännas en betydande grad av autonomi, en ganska långtgående rätt att bestämma reglerna inom sin domän. Detta beror både på att de är representativa och demokratiska företrädare för domänen, och på att de har kunskap och kompetens för uppgiften. $\AA$ andra sidan skall staten eller kommunerna kunna använda och rent av utnyttja organisationerna för att slippa ta över det som organisationerna ägnar sig åt. Skälen för detta är de samma - kanske i omvänd ordning. Organisationerna kan sitt område, och de är dessutom demokratiska företrädare för problemområdet.

Under det senaste seklet har utvecklingen av förhållandena mellan staten och organisationerna pendlat mellan dessa poler, autonomi och utnyttjande. Både autonomi och utnyttjande har kunnat motiveras med likartade argument. Organisationer som bara blir utnyttjade och förlorar sin korporativa autonomi, står dock utanför den "fria korporatismens« ordning, och kan förvandlas 
till rena affärsföretag. När organisationerna bara är autonoma och inte längre vill, kan eller får ställa sig till förfogande för statligt och kommunalt samhällsarbete är de också utanför denna ordning.
Kanske är det så att den "fria korporatismen« kommer att försvinna, kanske omförhandlas den nu i hela samhället. I båda fallen står vi inför betydande förändringar av organisationssystemen i Sverige.

\section{Summary}

\section{Voluntary organizations, social work and expertise.}

The theme of this article is the development of expertise in voluntary organizations within the area of social policy and social services. On the one hand, the growth and demand of expertise and professional skills is seen from the angle of the professionalization debate in social work, and on the other hand, as a factor in uncertain relation to the democratic content of the organizations.

Frequently, voluntary organizations are simplistically taken as paradigms of both lay enthusiasm and vital democracy, and public social work of professionalism. However, grey zones dominate the landscape, and hybrid forms and intermediate positions are numerous.

In the analysis of the relations between organizations and their environment, cooptation is conceived as an important process. Cooptation (e.g. by the State) usually occurs following the organization's deploy- ment of expertise and domain control in matters important to society. This may restrict the freedom of action of the organization, while, at the same time, protecting it and adding to its legitimacy.

In our discussion of these matters, we distinguish between two main types of organizations - each with its own possible plethora of subspecimens - which incarnate two different principles of operation; the "Ifor-you" organization and the "we-for-us" organization.

The conditions for development of expertise and the forms of cooptation and its consequences for democracy vary among these organizations. In addition, the ongoing transformation of the welfare state seems to greatly influence the collaboration patterns. This is shown by means of examples of Swedish voluntary organizations from different categories.

\section{Referenser}

Ahrne, G. (1994) »Organiseringen av det civila samhället", Sociologisk Forskning, nr 2, sid 3845.

Amnå, E. (red) (1995) Medmänsklighet att hyra. Åtta forskare om ideell verksamhet. Örebro: Libris.

Antman, P. (red) (1993) Systemskifte. Fyra folkhemsdebatter. Stockholm: Carlssons.
Beckman, S. (1981) Kärlekpå tjänstetid. Stockholm: Arbetslivscentrum.

Bergmark, Å. (1994) Från bidrag till ersättning? Om kommunernas stöd till de frivilliga organisationerna inom den sociala sektorn. Sköndalsinstitutets skriftserie nr 1. Stockholm: Sköndalsinstitutet.

Boalt, G. \& Bergryd, U. (1974) Centralförbundet 
för Socialt arbete. Ett kapitel svensk socialpolitik. Karlskrona: Abrahamssons.

Breckinridge, S. (1925) Family welfare work. Chicago: Chicago University Press.

Carlberg, A. (1991) "Södertörnsmodellen". Om möjligheterna att med kommunalt stöd starta ett arbetskooperativ för missbrukare. Stockholms läns landsting, Regionplane- och trafikkontoret. Idéserie om kooperation 5.

Castel, R. (1988) The Regulation of Madness. Cambridge: Cambridge University Press.

Christie, N. (1997) "AA och anarkins styrka", Nordisk alkohol \& narkotikatidskrift, Vol 14, nr 2, sid 110-113.

Davis, A. F. (1967) Spearheads for Reform. The Social Settlements and the Progressive Movement 1890-1914. New York: Oxford University Press.

Engman, T. (1992) Ett sätt att leva. Psykiatri-Samhälle. RSMH, en klientrörelses tillkomst och framväxt. Stockholm: Carlssons.

Etzioni, A. (1993) The Spirit of Community. Rights, Responsibilities and the Communitarian Agen$d a$. London: Fontana Press.

Flexner, A. (1915) "Is social work a profession?" i Proceedings of the National Conference of Charities and Corrections, sid 576-590, Chicago: Hildeman.

Fridell, M. (1996) Institutionella behandlingsformer vid missbruk. Organisation, ideologi och resultat. Stocholm: Natur och Kultur.

Gidron, B. Kramer, R. M. \& Salamon, L. M. (1992) Government and the Third Sector. Emerging Relationships in Welfare States. San Fransisco: Jossey-Bass.

Goldberg, T. (1993) Narkotikan avmystifierad. Stockholm: Carlssons

Gough, R. (1994) GIL-Projektet för lika villkor. Göteborg: Föreningen Ett självständigt liv.

Guidicini, P. \& Pieretti G. (1995) San Patrignano between Community and Society. Milano: FrancoAngeli.

Habermas, J. (1987) The Theory of Communicative Action. Vol 2: Lifeworld and System. Cambridge: Polity Press.

Hansson, J-H. \& Wijkström, F. (1997) »Basta! «Beskrivning och analys av Basta Arbetskooperativ .
Sköndalsinstitutets arbetsrapportserie, nr 3. Stockholm: Sköndalsinstitutet.

Heckscher, G. (1951) Staten och organisationerna.

Stockholm: Kooperativa förbundets förlag. (2:a uppl.)

Helmersson Bergmark, K. (1995) Anonyma Alkoholister i Sverige. Diss. Acta Universitatis Stockholmiensis, Stockholm Studies in Sociology. N.S. Stockholm: Almqvist \& Wiksell International.

Henriksen. L. S. (1996) Lokal frivillig organisering $i$ nye omgivelser. Aalborg Universitet: ALFUFF.

Høgsbro, K. (1992) Sociale problemer og selvorganiseret selvhjoelp i Danmark. Köpenhamn: Samfundslitteratur.

Jeppson Grassman, E. \& Svedberg, L. (1993) „Frivillig verksamhet på fältet - en närstudie av sju organisationer« i SOU 1993:82 Frivilligt socialt arbete. Kartläggning och kunskapsöversikt.

Jeppsson Grassman, E. \& Svedberg, L. (1995) „Frivilligt socialt arbete i Sverige - både mer och mindre« i Amnå E. (red.) Medmänsklighet att hyra? Atta forskare om ideell verksamhet. Örebro: Libris.

Jesperson, M. (1994) „Fountain House är ingen framtidsmodell ", Revansch!, vol 14, nr 4, sid 1618.

Larson, M. S. (1977) The Rise of Professionalism. A Sociological Analysis. Berkeley: University of California Press.

Laursen, L. (1996) "Scandinavia's tug of war on drugs" i Hakkarainen, P. m fl (red) Discussing Drugs and Control Policy. Comparative Studies on Four Nordic Countries. Helsingfors: NAD.

Levin, I. (1997) "To pionerer - to retninger", Nordisk Sosialt Arbeid, vol 17, nr 3, sid 162-169.

Lorentzen, H. (1994) „Moraldannende fellesskap» i Frivillighedscentraler i Norden. Rapport från FRIA-seminariet i Bergen 5/5-8/5 1994.

Lundström, T. (1995a) "Staten och det frivilliga sociala arbetet i Sverige« i Klausen, K. \& Selle, P. (red) Frivillig organisering i Norden. Oslo:Tano.

Lundström, T. (1995b) „Frivilligt socialt arbete under omprövning", Socialvetenskaplig tidskrift, vol 2, nr 1, sid 39-59.

Lundström, T. (1997) Barnavårdsorganisationer 
vid två sekelskiften. Sköndalsinstitutets skriftserie nr 10. Stockholm: Sköndalsinstitutet.

Lundström, T. \& Wijkström, F. (1995) Från röst till service? Den svenska ideella sektorn i förändring. Sköndalsinstitutets skriftserie nr 4. Stockholm: Sköndalsinstitutet.

Lundquist, L. (1997) Fattigvårdsfolket. Ett nätverk $i$ den sociala frägan 1900-1920. Lund: Lund University press.

Magnusson, J. (1997) Frivilliga organisationer och korporativ politik. Diss. Meddelanden från Socialhögskolan 1997:5. Lund: Socialhögskolan.

Mallander, O., Meeuwisse, A. \& Sunesson, S. (1998) "Normalisering och vardagsliv«i i Denvall, V. \& Jacobson, T. (red) Vardagsbegrepp $i$ socialt arbete. Stockholm: Norsteds Juridik.

Meeuwisse, A. (1997) Vänskap och organisering. En studie av Fountain House-rörelsen. Diss. Lund Studies in Social Welfare. Lund: Arkiv.

Michels, R. (1915) Political Parties. Glencoe, Ill.: Free Press.

Morris, J. (1993) Independent Lives? Community Care and Disabled Persons. London: Macmillan.

Offe, C. (1985) „New Social Movements: Challenging the Boundaries of Institutional Politics", Social Research, vol 52, nr 4, sid 817-868.

Olson, H-E. (1992) Staten och ungdomens fritid: Kontroll eller autonomi?. Diss. Lund: Arkiv.

Parsons, T. (1951) The Social System. Glencoe IL: Free Press.

Parsons, T. (1954) „The Professions and Social Structure" i Parsons, T. Essays in Sociological Theory. Glencoe IL: Free Press.

Peele, S. (1985) The meaning of addiction. Lexington, Mass: Lexington Books.

Qvarsell, R. (1993) „Välgörenhet, filantropi och frivilligt socialt arbete», i SOU 1993:82 Frivilligt socialt arbete. Kartläggning och kunskapsöversikt.

Rosenqvist, P. \& Stenius, K. (1989) „Folkrörelse, självhjälp och företagaranda. Har LP-stiftelsen och Minnesota-modellen något gemensamt?" Alkoholpolitik-Tidskrift för nordisk alkolforskning, vol 6, nr 4, sid 183-190.

Seip, A-L. (1984) Sosialhjelpsstaten blir til. Norsk sosialpolitikk 1740-1920. Oslo: Gyldendal.
Selle, P. (1996) Frivillige organisasjoner i nye omgjevnader. Bergen: Alma Mater.

Selznick, P. (1949) TVA and the Grass Roots. Berkely: University of California Press.

SOU 1993:82 Frivilligt socialt arbete. Kartläggning och kunskapsöversikt. Rapport av Socialtjänstkommittén. Socialdepartementet. Stockholm: Fritzes.

Spector, M. \& Kitsuse, J. I. (1977) Constructing Social Problems. Menlo Park, CA.: Cummings.

Sunesson, S. (1989) "Kooptation eller motoffensiv", Socialmedicinsk tidskrift, vol 66, nr 8, sid 406411.

Sunesson, S. (1992) "Problem och problematiseringar", Nordisk Sosialt Arbeid, vol 12, sid 5769.

Sunesson, S., m.fl. (1998) »The Flight from Universalism", European Journal of Social Work, vol 1, nr 1, sid 19-29.

Svedberg, L. (1996a) „Frivillighet som ideologiskt slagträ och faktisk verksamhet", i Ojämlikhet från vaggan till graven - på väg in i 2/3-samhället. FKF Fakta, 1996, sid 145-165.

Svedberg, L. (1996b) "A Scandinavian Voluntary Tradition in Transformation - The Case of Sweden«, Paper framlagt vid "Nätverket för forskning kring den nordiska ideella sektorn« i Oslo, november 1996.

Swärd, H. (1997) „Det Elberfeldska fattigvårdssystemet", Nordisk Sosialt Arbeid, vol 17, nr 2, sid 103 - 114.

Trägårdh L. (red) (1995) Civilt samhälle kontra offentlig sektor. Stockholm: SNS Förlag.

van Zanden Theis, S. (1924) How Foster Children Turn Out. New York: State Charities Association. Publication no 165.

Waltzer, M. (1992) „The Civil Society Argument» i Mouffe, C. (red) Dimensions of Radical Democracy. London: Verso.

Ågren, G. (1990) „Hur ser de LVM-vårdade missbrukarna ut, och hur förändras deras situatiuon i samband med vården?" i Forskning om missbrukare och vården, särskilt tvångsvården, sid 49-62. DSF:rapport. Stockholm. 